\title{
The Barter Trade and the Development of Tea Culture in the Ming and Qing Dynasties
}

\author{
Yuan Yao \\ University of Science and Technology of China, Hefei, China \\ Email:9818884@qq.com
}

How to cite this paper: Yao, Y. (2021). The Barter Trade and the Development of Tea Culture in the Ming and Qing Dynasties. Advances in Historical Studies, 10, 34-43.

https://doi.org/10.4236/ahs.2021.101004

Received: January 7, 2021

Accepted: March 8, 2021

Published: March 11, 2021

Copyright $\odot 2021$ by author(s) and Scientific Research Publishing Inc. This work is licensed under the Creative Commons Attribution International License (CC BY 4.0).

http://creativecommons.org/licenses/by/4.0/

\section{(c) (i) Open Access}

\begin{abstract}
Tea, one of the oldest beverages, moisturises and soothes the throat and promotes the health and fitness of the human body. Apart from these advantages, tea is also a carrier of culture that has endured the passage of time. Tea is native to China, and Chinese tea culture, as a precious form of ethnocultural heritage, has made important contributions to global tea culture as well. Barter trade has been an important means of exchange in tea culture, and the way of bartering and the subjective and objective factors involved in the trade process have had significantly different cultural impacts. This study on the connection between the barter trade and the development of tea culture, using case studies from the Ming and Qing Dynasties in China-with special reference to the time of the Opium Wars-helps to further explore the Chinese tea culture and comprehend its development in the contemporary world.
\end{abstract}

\section{Keywords}

Barter Trade, Tea, Opium Wars, Contemporary Tea Culture

\section{Introduction}

During the Ming and Qing dynasties, Japanese pirates (known as wokou) constantly threatened the security of the Chinese borders, in what is called the "Wokou Crisis". In retaliation, the Chinese imperial governments started to enforce certain regulations, which ultimately had the effect of contributing to Chinese seclusion. Due to this, the tea trade was in a state of depression for a long time, until the outbreak of the Opium Wars, when the Chinese imperial government was forced into unequal treaties with the British, including even the tea trade. As a result, Britain not only imported Chinese tea but also traded it with numerous other countries, which disseminated Chinese tea culture throughout the world. While the Opium Wars brought negative impacts to China in many 
respects, they did promote the global spread of Chinese tea culture. Exploring the post-war tea trade between China and Britain should not be merely a discussion on the development of the tea economy but should also involve cultural, political, and other aspects, which is the main purpose of this article. The Sino-British tea barter trade in the Ming and Qing Dynasties has been selected as the target of this research to expand on the impacts of various complicated factors on the tea culture and how those impacts were generated. This may be used as an effective reference for the development of traditional Chinese tea culture and how it can be better promoted in the rest of the world.

\section{The Tea Trade between China and Britain: The Causal Loop}

Barter trade is a commodity-denominated trade activity established by common practice among areas using different currencies that settles payments in the form of goods. The medium of barter trade is thus not limited to currency in circulation. Historically, trade has gradually gone through the stages of exchange of means of subsistence, exchange of commodities, and exchange of currency, each with associated trade activities (Zhang, 2006). The development of modes of trade in the exchanges between China and Britain during the Qing Dynasty featured a gradual progression of trade forms from gifts in return for "tribute" to monetary transactions and commodity exchanges. As we know, neither party in a transaction intends to lose money, which means that both pursue "equivalent value". It is worth noting that the complexity of the tea barter trade between China and Britain in the Qing Dynasty was not only embodied in the transition from one trade form to another but also in the difference of trading purposes.

1) Barter is nothing more than the pursuit of exchanges of equal value.

In the Ming and Qing Dynasty era before the Opium Wars, the tea barter trade always operated from a position of trade surplus, as tea was a staple commodity in the trade between China and Britain (Liang, 2019). The long- implemented seclusion policies had led the imperial government authorities to believe in the traditional idea of "self-sufficiency", and they refused to recognise changes in the world outside. The Qing government followed a "tributary system" in handling diplomatic relations with foreign countries-the Qing government gave gifts in return for "tribute", akin to a barter system (Liu, 2018a). In that process, the balance of the price tipped towards the tributary country, as the country that accepted the tribute was under no pressure regarding "value equivalence" or "additional values".

From one perspective, in the vast territory of China with its abundant natural resources, people were self-sufficient in means of livelihood. During the late Ming and early Qing Dynasties, feudal traditions of more than two thousand years were still deeply rooted. The government adopted the policy of "promoting agriculture and restraining commerce", restricting communication with the outside world and discouraging the seeds of capitalism. Against this background, the concept of monetary transactions was not widely accepted. In addition, there 
was not enough money to support merchandise trade, as silver currency existed only as an equivalent in people's daily life and the tributary system. However, the adequacy of material goods was essential for barter trade. From another point of view, the government chose to "build a cart behind closed doors", which was the deeper reason for the barter trade during the late Ming and early Qing dynasties. The Qing government was not intrinsically reluctant to accept science and technology; rather, the rulers gave up the opportunity to keep pace with the times in order to prevent the "political ecology" of China from being broken by the new spirit of "liberty and equality" with the arrival of science and technology into the country. However, their strategy greatly slowed down China's productivity growth. While China had abundant resources to provide people with means of livelihood, it also required "new things" and convenience products from Britain and other foreign countries. Goods that could not be produced at home due to technical challenges relied on importing, but while Britain's exports to China were limited to textiles and metal products, Britain had an urgent desire for Chinese tea, raw silk, and other products. In addition, the British anti-alcohol temperance movement also fuelled Britain's demand for Chinese tea (Dai, 2020), ensuring an external market for Chinese peasant farmers of tea. Given the above, it can be seen that there was a solid, realistic foundation for the adoption of goods as an intermediary instrument in barter trade.

Nevertheless, British colonialists were thwarted by the trade surplus and the Qing government's stubborn resistance to the sluggish domestic demand for goods under the seclusion policies, so they started to think about how to turn the tide on China's favourable balance of trade.

2) Currency as the trade medium for tea and silver.

While the seclusion policies limited the impact of foreign agricultural and subsidiary products on China's "natural" domestic economy, they also made the Qing government inattentive to Britain's efforts to protecting its own trade interests. During the reign of Emperor Daoguang (1821-1850), tea remained one of China's chief exports. Similar to tea, opium was first exported to China from Britain because of its medical benefits. Opium was used as a medicine for the relief of pain. However, as the old saying goes, "Every medicine has its side effect". Opium is highly addictive if overdosed. In the previous barter trade, the goods exchanged were of equivalent value, so it was very difficult for Britain to earn silver from Chinese people. Knowing the addictive potential of opium, Britain used it to erode people's minds and health, resulting in opium addiction among the Chinese, so as to achieve stable, soaring rise in opium exports.

At that time, imports of opium into China greatly exceeded its exports of commodities, such as tea. Barter trade in this context means a commodity exchange in the narrow sense, which uses currency as the medium of exchange. Furthermore, however, from the in-depth value analysis, we can clearly see the hidden ambition of the foreign powers behind the trade. The value of a commodity consists of two aspects: use-value and exchange-value. In the trade between China and Britain, unlike tea, opium was mainly used to feed people's ad- 
diction. Given this high use-value, the exchange-value of opium also rose accordingly. Clearly, the purpose of the barter trade between China and Britain, with silver as the medium, was to speed up the depreciation of silver in China. In the trade, the price of tea was far lower than that of opium. Though tea and opium provide similar medical benefits, there was a huge difference in profits between the two. It is thus evident that the purpose of trade for Britain at this stage, alongside accessing Chinese tea, was to make excessive profits from opium. However, this profiteering did not deter China from trading tea with Britain. With previously accumulated trade surpluses, it was difficult to quickly notice the disadvantages of this trade form, which offered equal volumes of goods with inequivalent values.

As a result, China suffered a heavy outflow of silver in the barter trade at this stage. Though tea remained a staple export item, its value addition to China's economy was far from enough to resist Britain's economic aggression against the Qing government through the opium trade, hence the heavy outflow of silver. In order to improve the situation, the Qing government proposed restrictive plans to fight against the foreign powers. It was stipulated explicitly that tea must be purchased with silver in the barter trade, making silver an equivalent. At that time, the medium of exchange became currency, in a measure aimed at suppressing the outflow of silver, which differed from the surface approach it usually took.

3) Conspiracy leads to opium abuse, causing a surge of demand in the market.

The side effects of the seclusion policies of the Ming and Qing Dynasties were devastating. The regimes tried to react to the economic scheme of the British using underdeveloped restrictive plans, as discussed above. Although the Qing Dynasty adopted certain methods to fight back, for example, using military forces to resist externally and controlling the distribution of opium internally, those actions had little effect. On the one hand, the Qing government's military weapons and means of transportation were out of date, compromising troop strength and combat speed. On the other hand, throughout the country, there was widespread opium abuse by a significant number of people, from high-ranking officials to commoners, leading to poor physical and mental condition. Due to these internal and external factors, the Qing government suffered failure in the Opium Wars and signed a series of humiliating treaties. In the process, the conspiracy of the British colonialists finally surfaced. As the saying goes, "laggers get beaten".

The Qing government was forced to set up many new trade ports for the convenience of British merchants, facilitating further economic exploitation. According to records, in Shanghai, there was a period when opium was used as an equivalent for tea in the barter trade between China and Britain, while, in fact, it was non-equivalent. The purpose of trade changed quietly at this stage as well, as it shifted from premium exchange to equivalent sales, and finally to a complete trade Waterloo with imposed discounts. The result was non-equal treaties, where one party deliberately abuses an imbalance and the other party is forced 
to endure.

According to relevant literature, opium found no eager buyers in China in 1782 , meaning that opium addiction was not widespread at that time. Similarly, the balance of trade between China and Britain was still not broken, nor was the difference in profits from the tea and opium trade. During the reign of Emperor Kangxi (1661-1722), the importation of opium was still allowed, and the country was not alert to the potential health or economic danger of the imports, as it was still contented with the solid economic foundation promoted by accumulated trade surpluses. However, the situation changed during the reign of Emperor Qianlong (1735-1796). The import of opium into China was banned, though the monitoring of the trade was far from enough. Opium was not eliminated for several reasons: First, as the British East India Company's opium trade with China grew rapidly, the trade was no longer simply a source of profit but a path for invasion. Second, Chinese people lacked mental and physical strength to fight against temptation to opium after long-term intake of it. In addition, China's backwardness in economy, science, and technology allowed opium to become a major "equivalent" in the trade between China and Britain.

\section{Development of Tea Culture: Complex Yet Prosperous}

Throughout the twists and turns in the China-Britain tea barter trade during the Ming and Qing Dynasties, the balance of economic interests between the two countries also tilted to different sides as the form of barter changed. If we look beyond national-level economic lens and consider the level of culture, which moves beyond borders, the impact of barter trade between the two countries concerning tea culture is worth researching on this level as well.

1) Tea lovers are its true connoisseurs.

As the famous Chinese saying goes, "what is rare is never swift horses themselves, but a sharp eye for swift horses". This means there are plenty of people with outstanding talents, but there are few people who are good judges of talent. The practice of tea-drinking emerged as early as the era of Shennong, the mythical father of herbal medicine. Tea culture refers to a series of cultural activities formed in, through, and around the process of tea-drinking, including the tea ceremony, tea rite, tea essence, tea painting, and tea art, to name just a few. Tea culture covers a wide range of ideas and methodologies. First, there are countless types of tea, such as Yellow Mountain Mao Feng Green Tea, Lu'an Melon Seed Tea, Smoked Beans Tea from the Taihu Lake, Suzhou Scented Tea, Hunan Ginger Salt Tea, Hangzhou Longing Tea, Fujian Oolong Tea, Taiwan Tung-ting Oolong Tea, Biluochun Tea, and Pu'er Tea. Second, there are various rules regarding the brewing process. Tea lovers around the world have different tea-drinking habits and preferences, each with its own idiosyncrasies.

Despite wars caused by the conflict of interest between China and Britain during the Ming and Qing dynasties, people's passion for tea never changed nor became distorted. People who love tea, who are its connoisseurs, are the main 
reason why the tea market continues to exist and be strong.

2) Pursuit of excellent quality, both internally and externally.

The cultural element in tea has a far greater significance than the function of quenching people's thirst. Since ancient times, tea has been celebrated in various ways, including through poetry, dance, and painting. Among the many reasons that explain people's love for tea, two are fundamental. First, tea quenches thirst and is good for health, as expressed in the following lines of a poem: "Tea leaves are picked from mountainous areas in spring, and brewing tea in an elegant environment like a bamboo forest is the best way of enjoying its fragrance". Second are its more ephemeral qualities. Tea leaves, beautiful and fragrant, evoke the appreciation of nature, as the poem describes, "in the late spring, I love the breeze with tea vapour and the falling flowers". Tea helps to refine one's mind, as is expressed in the lines: "The Pine Needle Tea and Snow Tea form a poetic dream, where, in the bamboo courtyard, the tea fragrance gives me more inspiration for writing". They stand as metaphors for the qualities of a noble spirit: "A gentleman's acquaintance is insipid as water, while a tea connoisseur's acquaintance is as rich as tea". In short, tea brings peace and joy, explaining the enduring prosperity of tea culture.

During the Ming and Qing Dynasties, as the natural economy in China was devastated, a few tea merchants began to adulterate their product with fake tea, to make more profit for themselves (Shi, Dong, \& Wei, 2018). As a result, China's tea exports began to decline, as British tea grown in India gradually caught up and became dominant. Poor quality has arguably been a major barrier to the modernization of traditional Chinese tea.

3) New strategies powered by technological advancement.

As discussed above, one factor enabling British tea to catch up with and surpass Chinese tea as a trade product was Britain's imposition of economic sanctions on China after the Opium Wars. Another important reason was the theft of Chinese tea technology by the British. Before the Opium Wars, China had existed as a centralised feudal system for two thousand years. Although the stability in the agriculture-based economy had not triggered significant development in tea quality, it provided a good environment for the development of tea culture. The invasion of China by British colonists changed the situation. First, by stealing tea-related techniques from China, Britain managed to provide a unique tea product in the global market with a substitute. Second, with advanced technologies, it was able to mass-produce tea at a significantly reduced cost compared to traditional household-based tea production. It continued to develop innovations in tea production technology and finally made "good yet affordable tea" a reality. Therefore, British tea became increasingly famous and seized the international market share previously owned by Chinese tea. At the same time, due to the issue of fake tea, as mentioned above, traditional Chinese tea culture entered a downward spiral (Zhong, 2018).

4) Marketing is indispensable, and tea is no exception.

From the China-Britain tea barter era in the Ming and Qing dynasties to the 
present, tea packaging and marketing have become increasingly creative and elaborate. Chinese tea is now marketed in English, increasing its brand recognition. The Opium Wars did not provide the most favourable conditions for promoting the prosperity and development of tea culture, because their profit-seeking nature of the wars fixated attention on sales increases when it came to learning tea culture and export, instead of research and cultural development (Liu, 2018b). At that time there was insufficient innovation in packaging. Of course, China was forced to open up its economy at a time when the translation of tea culture from Chinese into English for better promotion was considered a luxury. To make matters worse, the wars also caused certain historical traditions to vanish.

Through the above analysis of the barter trade between China and Britain in the Ming and Qing dynasties, we can see that China's position in the trade gradually became unfavourable. Even so, tea always occupied a large market share throughout the years, irrespective of whether the country had positive or negative trade balance, or whether it was regarded as a "gift from China", "commodity", or "gesture of goodwill". The position of tea in the market shows that tea had not only commodity value but also cultural value, shaped by the tea trade. Although the conflict of interest between China and Britain led to war during the Ming and Qing Dynasties, tea has thrived over time due to its health benefits and distinct fragrance. It has been loved and appreciated by many people, from poets and intellectuals to commoners. The premium quality of tea secured a strong market. Furthermore, the continuous development of science and technology undoubtedly was crucial for the development of the tea trade. Without changing the quality, more tea was produced at a lower price, with a greater aesthetic value, and tea became accessible to more people. The growth of tea sales also made it invincible in intertwined economic and political struggles.

After the war, while science and technology promoted the efficiency of tea production, people became less motivated to explore the cultural value of tea. To help the tea business flourish, in addition to continuous improvement of quality and cultural added value, it is also important to keep up with the times and promote the tea business with appropriate marketing strategies, technological means, and exquisite packaging.

\section{A Toast to the Future: Sharing the Same Pot of Tea and Celebrating Friendship}

1) Cultural convergence and mutual learning.

The tea trade was in depression during the era of barter trade between China and Britain, in the Ming and Qing Dynasties, due to both internal factors-as the government promoted agriculture and suppressed commerce-and external factors, as Japanese pirates raided the coastlines and colonists invaded the land. However, traditional Chinese tea was brought to other countries by Britain, as a result of the unequal treaties signed after the Qing defeat in the Opium Wars and went through cultural integration imposed by colonialism. Nowadays, Chi- 
na has risen to its current position on the global stage and is no longer subject to the exploitation of colonialism. Therefore, exchanges can be carried out by promoting language learning and translation of tea-related literature in both English and Chinese to promote the convergence of cultures and mutual learning (Zhang \& Cheng, 2018).

2) Stand together, differentiate, and innovate.

During cultural integration, the cultures of different countries vary to a certain extent, and common ground must be found while maintaining differences. At the same time, we should keep in mind that "science and technology constitute the foremost productive forces". First, advancement in science and technology can help to achieve accurate control of the production and processing time of tea leaves, which ultimately enhances tea craftsmanship and ensures that the essence of tea production can be inherited and maintained. Second, technology development also facilitates bundled sales of tea and accessories such as tea sets, packaging, and services, which promote the innovation of products. Third, technology enables e-commerce and enhances the reach and effect of media channels, which helps to establish brand recognition (Xu \& Gong, 2018). The cultural elements of tea can thus be promoted in all aspects and on multiple levels.

3) Toward friendship and prosperity.

"Harmony is most precious". Tea culture has long been an important part of traditional Chinese culture. To promote the value of tea culture and create global impact, it is necessary to maintain friendly relations with other countries so that the identity of tea culture can be established and be distributed to different places in a subtle way and on a daily basis (Zhu \& Wang, 2019).

In the context of economic globalisation, while China is no longer subject to British colonial aggression, it is still exposed to various threats, the most extraordinary of which is the China-US trade conflict. At the time of writing, the 2020 U.S. presidential election had just taken place, with its impact on the global economic landscape yet to be determined. In view of the long-term development of tea culture, there is no need to emulate Britain in the Ming and Qing Dynasties by making tea an economic weapon or suppressing the development of other countries as the US does. On the contrary, tea culture can be a means of communication. Using China's "greater circulation" to drive "dual circulation", may help China to break away from malicious economic interventions imposed by unfriendly states. The European Union is a possible breakthrough point. We can strive for cooperation by attending commodity fairs, establishing new rules in the international arena, and building a virtuous economic circle. By stabilising exchange rates and mediums in barter trade, China can achieve steady growth, create a harmonious environment, promote cultural prosperity, and promote the mutual development of tea culture.

4) The culture of bartering, adding to a new chapter of tea culture.

Before tea was traded as a commodity, China was self-sufficient in tea production. In Wang Bao's Tong Yue (also known as The Slave's Contract), he men- 
tioned that "[the servant shall] buy tea from Wuyang"; looking back at the emergence of the barter trade during the Ming and Qing dynasties, its development was dramatic, encapsulating the evolution of the value of tea from China's most important export in the $18^{\text {th }}$ century to the 1970s and 1980s, when, as the plots of foreign powers gradually unfolded, China's tea economy was stimulated and surged rapidly until it dominated the global tea market. After the 1880s, the tea market was under the influence of the foreign powers. Without advanced production technology and management strategies, Chinese tea lost its superiority in the market and was supplanted by foreign tea.

It is worth noting that as China's traditional tea industry gradually lost its economic centre in the barter trade, the influence of tea culture on cultural "exchange", "innovation" and "promotion" was also weakened, both in breadth and depth. The development of the tea industry was organically integrated with the development of the national economy and culture in the barter trade. Therefore, for long-term development, the role of tea in enriching material and spiritual civilisation can be advanced by enriching the connotation of barter trade. For example, we can see the tea industry in international exchange through the lens of culture. Tea products and building cross-cultural connections offer a medium for strengthening cultural identity, enhancing cultural exchanges, and promoting friendly intercourse between countries, so as to write a new chapter of tea culture!

\section{Conflicts of Interest}

The author declares no conflicts of interest regarding the publication of this paper.

\section{References}

Dai, Y. L. (2020). An Analysis of the Tea Parties during the British Temperance Movement in Victorian Age. Tea in Fujian, 42, 312-313.

Liang, S. (2019). An Analysis on the Tea Trade between China and Britain after the Opium Wars. Tea in Fujian, 41, 16-17.

Liu, L. M. (2018a). A Tentative Study on the Tea Trade in the Early Qing Dynasty. Tea in Fujian, 40, 55 .

Liu, N. (2018b). Research on English Translation of the Publicity Materials on Chinese Tea from the Perspective of Functional Equivalence. Tea in Fujian, 40, 321.

Shi, T., Dong, X. F., \& Wei, Y. (2018). A Study on Counterfeit Tea Issues in the Tea Trade between China and America in the First Half of the 19th Century. Journal of Shanxi University, Philosophy and Social Sciences Edition, 41, 46-56.

Xu, D. W., \& Gong, S. (2018). A Study on the Competitiveness of China's Tea Export and Enhancement Strategies. Tea in Fujian, 40, 46.

Zhang, K. (2006). The China-British Tea Barter Trade before and after the Opium Wars. Agricultural Archaeology, 5, 205-209.

Zhang, Q. L., \& Cheng, L. L. (2018). A Study on Art Design Inspirations for Improving Tea Packaging. Tea in Fujian, 40, 147. 
Zhong, Y. Q. (2018). On the Impact of Modern Science and Technology on Tea Trade. Agricultural Archaeology, 2, 118-124.

Zhu, S. H., \& Wang, T. S. (2019). A Study on the Value of Tea Culture of the Silk Road. Tea in Fujian, 41, 274. 